\title{
IŠORINIS OTITAS: \\ RIZIKOS VEIKSNIAI, DIAGNOSTIKA IR GYDYMAS
}

\author{
Julius Piluckis, Martyna Šopauskienė, Rugilè Dubickaitė \\ Lietuvos sveikatos mokslu universitetas, Medicinos akademija, Medicinos fakultetas
}

Raktažodžiai: išorinis otitas, plaukiko ausis, gydymas, antibiotikoterapija.

\begin{abstract}
Santrauka
Išorinis otitas, kitaip žinomas kaip ,plaukiko ausis“, yra išorinès klausomosios landos uždegimas. Jis gali būti infekcinis ir neinfekcinis. Išorinis otitas dažnai pasitaiko vyresniems nei 2 metu pacientams, 10 proc. populiacijos suserga šia liga nors kartą per gyvenimą. Darbo tikslas - susipažinti su išorinio otito rizikos veiksniais, diagnostika ir gydymu. Pasitelkiant LSMU virtualios bibliotekos šaltinius, buvo apžvelgta mokslinė literatūra nagrinèjamaja tema ir atlikta mokslinių straipsnių analizè. Daugumoje straipsnių buvo paminèti šie rizikos veiksniai: drègmès susilaikymas ausyse, ausų $\mathrm{pH}$ padidèjimas, imunosupresinè būklè, alerginès dermatozès, mechaninis klausomosios landos epitelio pažeidimas. Simptomai skirstomi ị specifiškus (ypač jautrus kramslys ir ausies kaušelis) ir nespecifiškus (ausies skausmas, otorejja, niežejimas, eritema ir klausomosios landos patinimas). Galimas kondukcinis klausos susilpnejimas. Liga diagnozuojama remiantis klinikiniais požymiais ir klausomosios landos uždegimo simptomais. Svarbu atlikti otoskopiją ar klausomosios landos ir ausies būgnelio (jei vizualizuojasi) otomikroskopinį ištyrimą. Jei ausies būgnelis nesivizualizuoja, reikia atlikti atrankinius klausos testus ar audiologini ištyrimą. Šie tyrimai atliekami diferencijuojant susirgimą nuo viduriniosios ausies uždegimo. Daugumai pacientų pakanka ambulatorinio gydymo. Kruopštus tualetas, valymas, sausumo palaikymas padeda užtikrinti tinkamą vietinio vartojimo medikamentų patekimą ị tolimają klausomosios landos dali. Ausų lašai su antibiotikais yra pirmo pasirinkimo gydymas pacientams, sergantiems ūminiu išoriniu otitu. Kombinuota vietine antibiotikų ir gliukokortikosteroidų terapija gydomų pacientų simptomai mažèja viena diena greičiau, nei vien tik vietinio vartojimo antibiotikais gydomų asmenų. Skausmo gydymas yra svarbi gydymo dalis. Lengvo ir vidutinio sunkumo skausmui malšinti
\end{abstract}

tinka paracetamolis ir geriamieji nesteroidiniai vaistai nuo uždegimo. Lašinti analgetikų nerekomenduojama, nes jų efektyvumas nepakankamas, jie galimai maskuoja būklès blogèjimą ar komplikacijų atsiradimą. Sisteminè antibiotikoterapija skiriama tik išskirtiniais atvejais ir tik po gydytojo otorinolaringologo ar gydytojo infektologo konsultacijos. Sunkesnès išorinio otito formos (furunkulas, piktybinis nekrozinis otitas, otomikozè, su dermatozèmis susijęs išorinis otitas) gydomos atsižvelgiant i jị sukèlusią priežastị, bendradarbiaujant su gydytoju otorinolaringologu.

\section{Ivadas}

Išorinis otitas - tai infekcinis arba neinfekcinis išorinès klausomosios landos uždegimas. Kai kuriais atvejais uždegimas gali išplisti ị išorinę ausị - kramslį ar ausies kaušelį. Išorinis otitas skirstomas ị ūminị (trunkantị iki 6 savaičių) ir lètinị (užsitęsiantị daugiau nei 3 mènesius). Retai pasitaikančios išorinio otito formos yra furunkulas ir piktybinis nekrozinis otitas. Išorinis otitas dažnai pasireiškia visose amžiaus grupėse, tačiau retai pasitaiko jaunesniems nei 2 metų pacientams. Vaikams ši liga dažniausiai pasireiškia nuo 7 iki 14 metų. Liga vienodai dažna moterims ir vyrams. Ja serga 10 proc. populiacijos, 95 proc. atvejų yra ūminiai. Ši liga dar vadinama „plaukiko ausimi“, nes dažnai diagnozuojama vasarą ar tropinio klimato šalyse. Vandens telkiniuose plaukiojantys žmonès paveikiami 5 kartus dažniau, negu nesimaudantys [1]. Dažniausiai išorinị otitą sukelia bakterijos. Alergijos, egzema bei žvynelinė gali turèti įtakos ligos manifestacijai, tačiau šios priežastys dažniau lemia lètinio išorinio otito atsiradimą [2].

Darbo tikslas - susipažinti su išorinio otito rizikos veiksniais, diagnostika ir gydymu.

\section{Tyrimo medžiaga ir metodai}

Literatūros paieška atlikta naudojantis LSMU virtualios bibliotekos prieiga prie elektroninių žurnalų PubMed, ClinicalKey, Cambridge Core. Naudoti raktažodžiai: otitis externa, Swimmer's ear, microbiology, epidemiology, 
treatment, antibiotic therapy. Iš viso atrinkta ir išanalizuota 13 publikacijų, paskelbtų 2010-2020 metų laikotarpiu.

\section{Tyrimo rezultatai}

Išorinio otito rizikos veiksniai. Dažniausiai nėra vieno aiškaus rizikos veiksnio, priežastys yra daugiafaktorinès. Bendrieji ūminị ir lètinị išorinị otitą sukeliantys veiksniai yra ausies sieros susikaupimas ir drègmès susilaikymas ausyse dèl siauro ar plaukuoto ausies kanalo, ausies sieros per didelio (kaupiasi drègmè) ar per mažo (prarandamos protekcinès savybės) išskyrimo. Perteklinė drègmė išorinèje klausos landoje (dažnai turint ilgą kontaktą su vandeniu) sukelia kanalo odos maceraciją, padidina $\mathrm{pH}$, pašalina apsaugini ausų sieros sluosnį. Spindulinè terapija, imunosupresinè būklè labai didina ligos pasireiškimo dažnį. A kraujo grupès asmenys genetiškai turi didesnị polinkị susirgti išoriniu otitu [3]. 2009 m. J. Kim ir J. Cho atliktame klinikiniame tyrime nustatyta, kad ligos sunkumas yra proporcingas $\mathrm{pH}$ padidèjimui $(\mathrm{p}<0,01)$. Normalus ausies $\mathrm{pH}$ yra $5,4 \pm 0,48$. Lengvo, vidutinio ir sunkaus išorinio otito metu $\mathrm{pH}$ kyla atitinkamai $6,34 \pm 0,35 ; 7,72 \pm 0,46 ; 7,53 \pm 0,32(p<0,01)$ [4]

Ūminio išorinio otito rizikos veiksniai yra išorinès klausomosios landos epitelio pažeidimas (dèl traumos, ar kito mechaninio poveikio nagais, medvilniniais higieniniais krapštukais) ar natūralios gynybos sutrikimas (kanalo drenavimosi obstrukcija, rūgštinės terpès sutrikdymas, aukšta aplinkos temperatūra). Lètinio - netinkamai gydytas ūminis išorinis otitas; nepaisant gydymo, persistuojanti bakterinè infekcija imunosupresiškiems asmenims; alerginis kontaktinis dermatitas išorineje ausies landoje, iritacinis kontaktinis dermatitas, atopinis dermatitas, seborejjinis dermatitas, navikai [5].

98 proc. infekcijų yra bakterinès, dažnai polimikrobinès: Pseudomonas aeruginosa (20-60\% atveju); Staphylococcus aureus (10-70\% atvejų, ìskaitant ir MRSA), kiti gramneigiami organizmai (2-3\% atvejų). Grybelinès infekcijos sukelia mažiau nei 2 proc. atvejų, tačiau ūminio išorinio otito vietiniam gydymui paskirti antibiotikai gali sukelti antrinę grybelinę infekciją. Aspergillus ir Candida yra dažniausi ligą sukeliantys grybai $[5,6]$.

Simptomai. Išorinio otito požymis yra stiprus ausies skausmas, ypač sustiprejjantis suspaudžiant kramslį, ar tempiant ausies kaušeli. Skausmas kyla kaulinejje išorinès klausomosios landos dalyje dèl antkaulio dirginimo. Šioje lokalizacijoje poodis nedengia antkaulio, o dermos sluoksnis yra labai plonas. Dažnai pasitaikantys simptomai yra otoreja, niežejimas, eritema ir klausomosios landos patinimas, kuris gali sukelti kondukcinį klausos susilpnèjimą [7,8].

Diagnostika. Liga diagnozuojama remiantis klinikiniais požymiais ir klausomosios landos uždegimo simptomais. Ji gali pasireikšti nuo lengvo diskomforto, niežèjimo ir lengvos edemos iki sunkaus skausmo, visiškos kanalo obstrukcijos ir aplinkinių audinių įtraukimo. Skausmo lygis tiesiogiai koreliuoja su ligos sunkumu. Galimas subfebrilus karščiavimas, tačiau kūno temperatūra, didesnè nei $38,3{ }^{\circ} \mathrm{C}$, leidžia įtarti uždegimo išplitimą i gilesnius audinius [9].

Būtina atlikti otoskopiją ar klausomosios landos ir ausies būgnelio (jei vizualizuojasi) otomikroskopinį ištyrimą. Nereikia užmiršti ausies kaušelio, aplinkinių limfmazgių ir odos ištyrimo. Jei ausies būgnelis nesivizualizuoja, reikia atlikti atrankinius klausos testus ar audiologinį ištyrimą. Tai svarbu, norint atmesti vidurinès ausies uždegimą. Esant patinusiai klausomajai landai, atliekamas kamertono testas ar audiograma. Šie tyrimai parodo kondukcinį klausos praradimą - galimai pažeistą būgnelị, net ir jo nematant. Išoriniam otitui būdinga padidejusi klausomosios landos sekrecija - sekretas gali būti panaudotas mikrobiologiniam tyrimui ir pasèliui $[6,8,10]$.

Diagnostikos kriterijai [8]. Ūminis išorinis otitas diagnozuojamas, jei per pastarąsias 3 savaites (dažniausiai per 48 val.) atsirado šių klausomosios landos uždegimo simptomų ir požymių:

- ausies skausmas (dažnai sunkus), niežèjimas, užgulimas;

- klausos praradimas (arba ne) ar skausmo sustiprejimas ausyje ir temporomandibuliniame sąnaryje, judinant apatini žandikaulį;

- kramslio ar (ir) ausies kaušelio jautrumas arba išplitusi klausomosios landos edema ar (ir) eritema su ar be otorejos, regioninių limfmazgių padidèjimo, būgnelio eritemos, ausies kaušelio ir aplinkinès odos celiulito [8].

Gydymas. Daugumai pacientu pakanka ambulatorinio gydymo. Ūminio išorinio otito gydymo algoritmas pateikiamas 1 pav. I stacionarą siunčiami sergantieji komplikuotu (pvz., piktybiniu) išoriniu otitu, imunosupresiški, blogejjančios būklès pacientai (nepaisant maksimalaus gydymo) [5].

Gydytojo otorinolaringologo konsultacijai turètų būti siunčiami pacientai:

- turintys ausyje svetimkūní, kurio nepavyksta pašalinti;

- kai nepavyksta pašalinti klausomosios landos obstrukciją sukèlusių nešvarumų;

- jei taikant standartinị gydymą, būklè negerejja arba blogèja (sisteminę antibiotikoterapiją rekomenduojama skirti tik po gydytojo otorinolaringologo konsultacijos);

- jei įtariamas piktybinis ar lètinis išorinis otitas, neatsižvelgiant į gydymo eigą [5].

Skausmo gydymas. Didžioji dalis nekomplikuotų išorinių otitų gydomi vietiškai vartojant antibiotikų lašus ir vaistus nuo skausmo. Skausmo lygis gali būti nuo lengvo iki sunkaus, todèl turi būti atitinkamai malšinamas. Pirminis anal- 


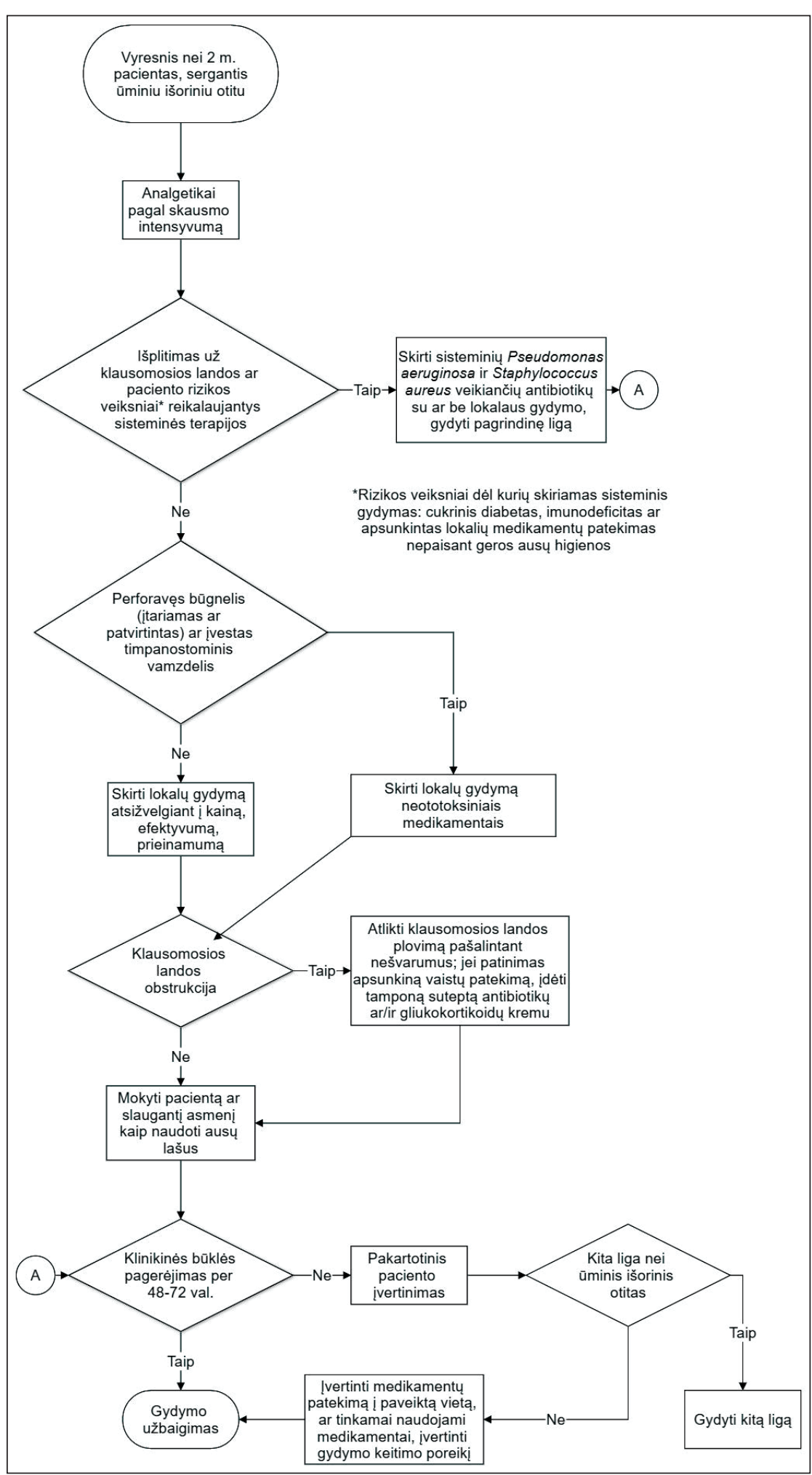

1 pav. Ūminio išorinio otito gydymo algoritmas Šaltinis: sudarytas autoriu pagal R. Rosenfield ir kt. (2014) [1] getikų vartojimo būdas yra peroralinis.

- Lengvam ir vidutinio sunkumo skausmui malšinti tinka paracetamolis ir nesteroidiniai vaistai nuo uždegimo $[1,11]$.

- Stipriam skausmui malšinti rekomenduojami opioidai (oksikodonas ar kodeinas), juos galima paskirti tik trumpam laikui (iki 48-72 val), nes ịprastai nekomplikuoto išorinio otito simptomai aprimsta per 48 valandas nuo lokalių antibiotiku vartojimo pradžios. Jei skausmas išlieka po 48 valandų nuo gydymo pradžios, rekomenduojamas kartotinis ištyrimas pirminès sveikatos priežiūros grandyje. Skiriant opioidus, sunkiau pastebèti būklès blogèjimą ar komplikacijų atsiradimą. Opioidų dèl kvèpavimo centro slopinimo neskirti sergantiems astma, LOPL, ar galvos traumą patyrusiems asmenims [1].

- Lokaliai lašinti analgetikų nerekomenduojama, jų efektyvumas nepakankamas, galimai jie maskuoja būklès blogèjimą ar komplikacijų atsiradimą [3].

Nemedikamentinis gydymas ir ausu priežiūra. Kruopštus ausų tualetas (valymas, sausinimas) padeda užtikrinti tinkamą medikamentų patekimą ị tolimają klausomosios landos dalị. Prieš išleidžiant pacientą, reikia atlikti ausų valymą ir (ar) įdèti tamponą, esant indikacijų [5].

Ausų tualetui naudojamas kūno temperatūros skystis (vanduo, fiziologinis tirpalas ar vandenilio peroksidas), kuris po valymo nusiurbiamas ir (ar) sausai išvalomas medvilniniu aplikatoriumi. Pašalinamas susikaupęs ausies sekretas ir svetimkūniai. Nedrèkinti nekontroliuojamu cukriniu diabetu sergančių, imunosupresiškos būklès pacientų ausų, ar esant pažeistam būgneliui [5].

Ausų tamponai (pagaminti iš celiuliozès ar marlès) atsargiai ịkišami ị klausomają landą, užtikrinant antibiotikų patekimą i tolimają landos dalį. İkišti tamponai sudrèkinami 6 antibio- 
tikų lašais. Indikuotini esant (arba numatant) klausomosios landos edemai. Iprastai tamponai iškrenta po kelių dienų, pagerèjus būklei. Tamponui neiškritus, pacientas gali ji išsiimti pagerèjus būklei, arba tamponas gali būti išimtas kartotinio vizito pas gydytoją metu [12].

Svarbu išmokyti pacientus tinkamai susilašinti ausų lašus. Iki 40 proc. pacientų neteisingai vartoja ausų lašus [5]. Tinkamo ausų lašų vartojimo seka: pacientas atsigula ant šono pažeista ausimi i viršų; geriausia, jei kitas asmuo lašina vaistus, kol prisipildo klausomoji landa; kramslị ir kaušelị reikia pamasažuoti, švelniai patempti, kad būtų užtikrintas visiškas landos prisipildymas vaistu ir išvengta oro susilaikymo landoje; medikamentus ausyje laikyti 3-5 minutes [3].

Rekomenduojama vengti drègmès ausyse. Saugoti ausis nuo vandens, vengti klausos aparatų, ausinukų, kol jaučiamas skausmas ir yra išskyrų. Sausai išvalyti ausis po sąlyčio su drègme, nenaudojant medvilninių higieninių krapštukų [11].

Vietinis gydymas. Ausų lašai su antibiotikais yra pirmo pasirinkimo gydymas pacientams, sergantiems ūminiu išoriniu otitu. Jie yra saugūs ir gerai toleruojami. Jų saugumas ir efektyvumas įrodyti randomizuotose studijose ir metaanalizèse. Antibiotikai, skirti vietiniam vartojimui 7 dienas, yra labai efektyvūs. Alternatyva antibiotikams - antiseptiniai (rūgštinantys) tirpalai, tinkami sergant lengvu ūminiu išoriniu otitu, kai nepažeistas būgnelis. Vietinis gydymas užtikrina aukštą vaisto koncentraciją pažeistame audinyje. Vietinis antibiotikų vartojimas leidžia pasiekti 100-1000 kartų didesnes vaisto koncentracijas, nei sisteminiai antibiotikai $[1,9,11,13]$.

Vietiniai ototoksiški medikamentai neturètų būti skiriami pacientams, esant pažeistam būgneliui (perforacija, timpanostominis vamzdelis), ar kai būgnelis nevizualizuojamas. Vietiniai ototoksiški medikamentai, patekę i vidinę ausies dali, gali sukelti klausos praradimą, svaigimą. Ototoksiniais laikomi: rūgštinančios medžiagos, aminoglikozidai (neomicinas, gentamicinas, tobramicinas), alkoholis ir kiti antiseptikai [8]. Vaikams būgnelio defektą įtarti, jei jiems pastaraisiais metais buvo įdetas timpanostominis vamzdelis; patekus medikamentams ị klausomąą landą, gali jausti jų skonị; gali išpūsti orą per ausị [7].

Antibiotiką parinkti atsižvelgiant ị alergijas, ototoksiškumą, vietinị atsparumą ir dozavimo paprastumą.

Sergančiu ūminiu išoriniu otitu ir kombinuota lokalia antibiotikų ir gliukokortikosteroidų terapija gydomų pacientų skausmas sumažejja viena diena anksčiau, nei gydomų tik lokalaus vartojimo antibiotikais [5]. R. Mösges ir kt. 2007 m. publikuotoje studijoje pastebejo, kad pacientų, gavusių kombinuotą antibiotikų ir hidrokortizono gydymą, simptomai lengvejjo greičiau, nei gydytų tik antibiotikais $(\mathrm{p}<0,05)$. Kartotinio vizito metu daugiau buvo besimptomių pacientų, paraudimas sumažèjo $14(56 \%)$ prieš $7(28 \%)$ be hidrokor- tizono, $\mathrm{P}=0,045$, sekrecija $23(70 \%)$ prieš $10(40 \%)$ be hidrokortizono, $\mathrm{P}=0,024$ [13].

Iš acto rūgšties sudaryti medikamentai gali būti naudojami esant lengvai formai, tačiau jų efektyvumas blèsta gydant ilgiau nei 7 dienas, simptomai išlieka 2 dienomis ilgiau, nei gydant antibiotikais [3,5].

Veiksmingo ūminio išorinio otito gydymo požymiai yra skausmo ir kitų simptomų sumažèjimas per 48-72 valandas [11].

Neskirti gliukokortikosteroidų ir antibiotikų lašų daugiau nei dvi savaites - skiriant šiuos vaistus ilgiau nei dvi savaites, didèja sensibilizacijos, antibiotikų atsparumo, grybelinès infekcijos atsiradimo rizika.

Sisteminis gydymas. Sisteminè antibiotikoterapija taikoma išskirtiniais atvejais, tik po gydytojo otorinolaringologo ar infektologo konsultacijos:

- esant didelei komplikacijų rizikai (imunosupresiškos būklès, diabetu sergantys, galvos spindulinę terapiją gavę, didelę piktybinio išorinio otito riziką turintys pacientai);

- esant uždegimo plitimo ị aplinkinius ar gilesnius audinius, ar didelei būklès blogèjimo rizikai;

- esant sunkiai ligos formai (klausomosios landos obstrukcija ar edema, sunkinanti vietinio vartojimo antibiotikų patekimą);

- išliekant išoriniam bakteriniui otitui po vietinès antibiotikoterapijos kurso [1,5,8,11].

Sisteminei antibiotikoterapijai nerekomenduojama skirti cefalosporinų, penicilinų ir makrolidų dèl didelès atkryčio tikimybès, didëjančio ligos sukèlèjų atsparumo [1].

Grybelinès klausomosios landos infekcijos atveju:

- derinti chirurgini klausomosios landos išvalymą su vietine antigrybeline terapija (klotrimazolo 1\% kremas) po gydytojo otorinolaringologo konsultacijos;

- gydytojo kabinete aplikacija genciano violetu yra efektyvi gydymo alternatyva;

- rūgštinančios medžiagos kartu su pagrindiniu gydymu padeda naikinti infekciją;

- nepasiduodančias gydymui grybelines infekcijas gydyti peroraliniu itrakonazolu;

- vietiné antibiotikoterapija kontraindikuotina, nes antibiotikai skatina grybų augimą $[1,5]$.

Lètinio išorinio otito atveju rekomenduojama kruopšti ausų higiena (jei ją galima taikyti), siekiant išvengti ligos paūmèjimo. Gydymas turètų būti orientuotas ị ligos priežastị [11].

Kontaktinio dermatito atveju vengti dirgiklių; vietiškai vartoti vidutinio (triamcinolono $0,01 \%$ kremas) ar didelio stiprumo (mometazono furoato $0,1 \%$ kremas) gliukokortikosteroidus, sergant kontaktiniu dermatitu ar kitoms lètinèmis ligomis. Vietiškai vartojamas takrolimas yra efektyvus antro pasirinkimo vaistas, nesant infekcijos. Jei reikia, gali būti pa- 
skirtas trumpas peroralinių gliukokortikosteroidų kursas [5].

JAV maisto ir vaistu administracijos patvirtinti vaistai išoriniam otitui gydyti [5]:

Acto rūgšties lašai - vyresniems nei 3 metų pacientams. Lašinti 4-6 lašus kas 2-3 valandas.

Acto rūgšties/hidrokortizono lašai - vyresniems nei 3 metų pacientams. İdèti medvilninị tamponą ị klausomają landą ir sudrèkinti tirpalo lašais. Palaikyti drègną tamponą, kas 4-6 valandas sulašinant po 3-5 lašus. Keisti tamponą ne rečiau, nei kartą per 24 valandas. Praejjus 24 valandoms po tampono įdejjimo, galima ji pašalinti, tačiau toliau lašinti po 3-5 lašus 3-4 kartus per dieną iki būklès pagerèjimo.

Ciprofloksacino lašai (Ciprofloxacini hydrochloridum) - vaikams iki 18 metų. 7 dienas kas 12 valandų lašinti po $0,5 \mathrm{mg}(0,25 \mathrm{ml})$ ị pažeistą klausomają landą.

Ciprofloksacino/hidrokortizono lašai - vyresniems nei 1 metų pacientams. 7 dienas kas 12 valandų lašinti po 3 lašus ì pažeistą klausomają landą.

Ciprofloksacino (deksametazono) suspensija - vyresniems nei 6 mènesių pacientams. 7 dienas kas 12 valandų lašinti po 4 lašus ị pažeistą klausomają landą.

Neomicino/polimiksino/ hidrokortizono lašai - visų amžiaus grupių pacientams, ịskaitant kūdikius:

- jaunesniems nei 18 metu pacientams 3-4 kartus per dieną lašinti po 3 lašus ị pažeistą klausomają landą. Nerekomenduojama gydymo tęsti ilgiau nei 10 dienų;

- vyresniems nei 18 metu pacientams 3-4 kartus per dieną lašinti po 4 lašus ị pažeistą klausomają landą. Nerekomenduojama gydymo tęsti ilgiau nei 10 dienų.

Oflaksacino lašai:

- tinka vyresniems nei 6 mènesių pacientams. Pacientams nuo 6 ménesių iki 13 metų 7 dienas vieną kartą per dieną lašinti 5 lašus $(0,75 \mathrm{mg} ; 0,25 \mathrm{ml})$ ị pažeistą klausomają landą;

- vyresniems nei 13 metų pacientams 7 dienas vieną kartą per dieną lašinti 10 lašų $(1,5 \mathrm{mg} ; 0,5 \mathrm{ml})$ ị pažeistą klausomają landą.

Klotrimazolo tirpalas - otomikozės atveju vyresniems nei 2 metų pacientams. Tepti pažeistą odą ir aplinkinį plotą du kartus per dieną. Gydymą tęsti iki simptomų sumažèjimo ir dar dvi savaites.

Lokalūs gliukokortikosteroidu tepalai - sergantiems lètiniu išoriniu otitu su kontaktiniu dermatitu ar kitomis lètinėmis dermatologinèmis ligomis:

- triamcinolono acetonido $0,01 \%$ tepalas - suaugusiems. Du kartus per dieną mažu kiekiu tepti klausomąą landą;

- mometazono furoato $0,1 \%$ tepalas - vyresniems nei 2 metų pacientams. Tepti pažeistą odą plonu sluoksniu ir itrinti vieną kartą per dieną [13].

Sisteminiai antibiotikai. Skiriami retai, tik po gydytojo otorinolaringologo ar infektologo konsultacijos [1]. Indikacijos: imunosupresija, cukrinis diabetas, uždegimo išplitimas i aplinkinius ar gilesnius audinius ar didelè būklès blogẻjimo rizika:

- ciprofloksacino tabletès - vyresniems nei 18 metų pacientams. 7-14 dienų du kartus per dieną 500-750 mg.

Prognozè. Sergantiems ūminiu išoriniu otitu paskyrus tinkamą gydymą, simptomai gerèja sparčiai: dažnai jau po vienos gydymo dienos pacientai jaučia pagerèjimą; dauguma po 4 gydymo dienų beveik arba visiškai nebejaučia skausmo [5].

\section{Išvados}

1. Svarbiausi išorinio otito rizikos veiksniai yra drègmès susilaikymas ausyse, ausų pH padidejimas, imunosupresinè būklè, alerginès dermatozès, mechaninis klausomosios landos epitelio pažeidimas.

2. Išorinis otitas diagnozuojamas remiantis klinikiniais požymiais ir klausomosios landos uždegimo simptomais. Otoskopija ir otomikroskopinis klausomosios landos ir ausies būgnelio tyrimas yra svarbi diagnostikos dalis.

3. Gydymas dažniausiai medikamentinis ambulatorinis. Kruopšti ausų higiena padeda užtikrinti tinkamą medikamentų veikimą. Vietiniai antibiotikai derinyje su peroraliniais analgetikais yra tinkami išoriniam otitui gydyti.

\section{Literatūra}

1. Rosenfeld RM, Schwartz SR, Cannon CR, Roland PS, Simon GR, Kumar KA, et al. Clinical practice guideline: acute otitis externa. Otolaryngol Neck Surg 2014;150:1-24.

https://doi.org/10.1177/0194599813514365

2. McKean SA, Hussain SSM. Otitis externa. Clin Otolaryngol 2007;32(6):457-9.

https://doi.org/10.1111/j.1749-4486.2007.01572.x

3. Kaushik V, Malik T, Saeed SR. Cochrane review: interventions for acute otitis externa. Evidence-Based Child Health: A Cochrane Rev J 2011;6(2):444-560.

https://doi.org/10.1002/ebch.711

4. Kim JK, Cho JH. Change of external auditory canal $\mathrm{pH}$ in acute otitis extema. Ann Otol Rhinol Laryngol 2009;118(11):769-72. https://doi.org/10.1177/000348940911801104

5. Wipperman J. Otitis externa. Prim Care 2014;41(1):1-9. https://doi.org/10.1016/j.pop.2013.10.001

6. Liu Z, Slim MAM, Scally C. Otitis externa in secondary care: a change in our practice following a full cycle audit. Int Arch Otorhinolaryngol 2018;22(3):250-2.

https://doi.org/10.1055/s-0037-1606621

7. Wiegand S, Berner R, Schneider A, Lundershausen E, Dietz A. Otitis externa. Dtsch Arztebl Int 2019;116(13):224-34.

8. Hui CPS. Acute otitis externa. Paediatr Child Heal 2013;18(2): 96-8. 
https://doi.org/10.1093/pch/18.2.96

9. Schaefer P, Baugh RFB. Acute otitis externa: an update. Am Fam Physician 2012;86(11):1055-61.

10. Walton L. Otitis externa. BMJ 2012;3623(May):1-3. https://doi.org/10.1136/bmj.e3623

11. Lee H, Kim J. Ear infections: otitis externa and otitis media. Prim Care 2013;40(3):671-86.

https://doi.org/10.1016/j.pop.2013.05.005

12. Bola S, Rashid M, Hickey S. Optimising the use of otowicks in otitis externa. J Laryngol Otol 2017;131(9):809-12.

https://doi.org/10.1017/S002221511700144X

13. Mösges R, Domröse CM, Löffler J. Topical treatment of acute otitis externa: clinical comparison of an antibiotics ointment alone or in combination with hydrocortisone acetate. Eur Arch Oto-Rhino-Laryngology 2007;264(9):1087-94.

https://doi.org/10.1007/s00405-007-0314-0

\section{OTITIS EXTERNA:}

\section{RISK FACTORS, DIAGNOSIS AND TREATMENT} J. Piluckis, M. Šopauskienė, R. Dubickaitė

Keywords: otitis externa, Swimmer's ear, microbiology, epidemiology, treatment, antibiotic therapy, combined treatment with antibiotic and steroid.

Summary

Otitis externa also known as ,swimmer's ear“ is external auditory canal inflammation. It can be with or without infection. Otitis externa occurs often in older than 2 years old population, $10 \%$ of all population suffer from this disease once in a lifetime. Many authors emphasize these risk factors: dampness in ears, increased ear $\mathrm{pH}$ levels, immunosuppression, allergic dermatoses, mechanical auditory canal injuries. Symptoms are specific (especially tender tragus and pinna) and nonspecific (otalgia, otorrhea, pruritus, erythema and edema of auditory canal). Conductive hearing loss is also possible. Disease diagnosis is based on clinical findings and auditory canal inflammation symptoms. It is important to perform otoscopy and auditory canal and acoustic membrane (if visualized) otomicroscopic examination. If acoustic membrane is not visualized, selective hearing tests and audiological evaluation must be performed. These tests help in differential otitis media diagnosis. Ambulatory treatment is sufficient for majority of patients. Aural toilet, cleaning, dryness in ear assures topical medicaments accessibility to distal ear. Aural antibiotic drops are first line choice for otitis externa treatment. Topical antibiotic combined with glucocorticorticosteroid results in faster symptoms decrement than using only topical antibiotics. Pain management is important part of otitis externa treatment. For light and medium pain acetaminophen and oral non-steroidal anti-inflammatory drugs are best choice. Topical analgetic drops are not recommended, efficiency is not sufficient, and they can mask condition decline or complications emerge. Systemic antibiotic therapy is prescribed in rare cases and only after ENT specialist or infectiologist referral. More severe forms of otitis externa (furuncle, malignant necrotic otitis externa, otomycosis, with dermatoses associated otitis externa) are treated at addressing and controlling underlying cause in cooperation with ENT doctor.

Correspondence to: julius.piluckis@gmail.com

Gauta 2020-11-23 